\title{
A moda faz furor no mundo intelectual
}

\author{
Maria Claudia Bonadio ${ }^{1}$ \\ ORCID: http://orcid.org/0000-0001-9704-9780
}

Este é o número 27 da dObra[s], o terceiro publicado em 2019, ano em que a revista deixou de ser semestral para ter periodicidade quadrimestral. É preciso comemorar essa mudança, pois, apesar da ampliação do trabalho provocada pela produção de um terceiro volume no ano, a amplificação da quantidade de números lançados em um mesmo ano é também decorrência do crescimento dos estudos sobre moda e temas afins produzidos no Brasil e no exterior. Ou seja, publicar três números no ano é uma necessidade, e a máxima cunhada por Gilles Lipovetsky em $O$ império do efêmero (1989), tantas vezes citadas em trabalhos acadêmicos, de que "a moda não faz furor no mundo intelectual", cada dia mais parece ultrapassada. Não só dObra[s] ampliou o número de edições, como no Brasil, títulos como Modapalavra e REAMD (Revista de Ensino em Artes, Moda e Design) não param de crescer, o que nada mais é do que decorrência da ampliação dos estudos científicos sobre moda e temas afins.

A moda hoje vem sendo problematizada a partir de diferentes perspectivas teóricas e a partir de diferentes áreas. É objetivo da dObra[s] veicular uma pluralidade de abordagens tanto na seção de artigos submetidos em fluxo contínuo como nas resenhas, nas entrevistas e nos dossiês.

Neste número, o dossiê Práticas corporais e moda esportiva: investigando sujeitos, roupas, performances, organizado pelos cientistas sociais Wagner Xavier de Camargo (UFSCAR) e Elisabeth Murilho da Silva (UFJF), reúne artigos que tratam da relação entre roupas, práticas corporais e esporte a partir de temas como a propagação da prática do ciclismo no fim do século XIX e as roupas para a realização do esporte; a difusão das modas associadas a esportes a partir do audiovisual (cinema e telenovela); os usos e consumos dos uniformes esportivos e a performatividade dos surfistas de trem.

As imagens que ilustram a capa e o interior da edição são de autoria do artista colombiano Andrés Leonardo Caballero Piza e se conectam ao tema do dossiê ao colocar em questão a relação entre esportes, virilidade e heteronormatividade. Ao Léo, deixo o agradecimento pela cessão das ilustrações.

\footnotetext{
${ }^{1}$ Editora-chefe da revista dObra[s]. Doutora em História e professora da Universidade Federal de Juiz de Fora. E-mail: mariacbonadio@uol.com.br. Lattes: http://lattes.cnpq.br/3920027222039096.
} 
O bloco que reúne artigos recebidos em fluxo contínuo traz cinco textos que foram organizados a partir de suas temáticas mais amplas, com vistas a permitir o diálogo entre eles quando possível. Os dois primeiros artigos apresentados na seção têm pontos de conexão, pois tratam, a partir de diferentes fontes e perspectivas teóricas, questões relacionadas aos usos das roupas, às poses e às aparências em fotografias como forma de contestar padrões de gênero.

No artigo Juventude "transada": tensionamentos das normativas de gênero na moda promovida pela revista Pop (anos 1970), as autoras Maureen Schaefer França e Marinês Ribeiro dos Santos analisam um editorial de moda veiculado na revista Pop em 1973. A publicação foi o primeiro mensário brasileiro exclusivamente dedicado ao público juvenil e que tentava atingir moças e rapazes. As autoras observam como o conteúdo das fotografias e os textos propõem uma maneira de vestir despojada e que dialogava com a contracultura, notando como tais aparências tensionavam os papéis de gênero há muito tempo cristalizados, mesmo em uma sociedade na qual o governo propagava valores conservadores.

Em Queer avant la lettre: moda e performance de gênero nos autorretratos de Claude Cahun, de autoria de Emerson Meneses e Martin Jayo, o foco do trabalho é a relação entre imagem fotográfica, roupas e identidade de gênero. Como informa o título, as fontes analisadas no texto são os autorretratos de Claude Cahun, nos quais a artista, em diálogo com o Surrealismo, utilizava-se das aparências como forma de colocar em questão o binarismo de gênero.

As conexões entre moda e arte também são abordadas em Moda no museu: os vestidos-objeto de Olly Reinheimer no MAM-RJ (1969), no qual Clecius Campos examina, a partir da repercussão em jornais cariocas, a importância da crítica de arte para a legitimação da referida exposição realizada no Museu de Arte Moderna do Rio de Janeiro e de Olly Reinheimer no campo das artes. Segundo o autor do texto, a mostra pode ser considerada o ponto mais alto da carreira da artista, mas, para além disso, o texto, mesmo que indiretamente, evidencia que as conexões entre arte e moda também encontraram espaço no Brasil, o que é, de modo geral, ainda pouco estudado.

0 último texto da seção, Expertise e legitimidade: os bureaux de style e a moda contemporânea, de autoria de Amanda Queiroz Campos, trata de um tema mais atual e ligado ao mercado de moda: o papel dos escritórios de estilo dentro do funcionamento do sistema de moda contemporâneo. E ainda como as empresas do ramo investem para legitimar a si mesmas como especialistas indispensáveis para a sobrevivência das marcas de moda.

Também compõe o número a resenha do livro de Izabela Domingues e Ana Paula de Miranda, Consumo de ativismo, publicado em 2018 pela editora Estação das Letras e Cores, denominada Consumo de ativismo: moda e comportamento na era das redes sociais e de autoria de Larissa Molina Alves.

Para fechar a edição, apresentamos uma entrevista realizada por Henrique Grimaldi, esta editora e Rita Morais de Andrade com a socióloga britânica Joanne Entwistle, que este- 
ve no Brasil em setembro de 2019 para realizar a abertura do 15o Colóquio de Moda. A pesquisadora é autora de inúmeros livros e pode ser considerada uma das principais referências para os fashion studies em âmbito internacional, mas ainda não tem livros nem sequer artigos traduzidos para o português, desse modo, a entrevista tem por objetivo aproximar o leitor lusófono do trabalho da entrevistada.

Para encerrar, cabe registrar que, nos últimos meses, a revista foi indexada em dois novos portais, o Portal de Periódicos Capes e o AmeliCA.

Boa leitura,

Maria Claudia Bonadio

Editora-Chefe 